\title{
An unusual presentation of a typical complication after endoscopic polypectomy
}

\author{
Franz Ludwig Dumoulin, ${ }^{1}$ Jochen Textor ${ }^{2}$ \\ ${ }^{1}$ Department of Medicine, Gemeinschaftskrankenhaus Bonn, Bonn, Germany; \\ ${ }^{2}$ Department of Radiology, Gemeinschaftskrankenhaus Bonn, Bonn, Germany
}

Correspondence to Mr Franz Ludwig Dumoulin, f.dumoulin@gk-bonn.de

\section{DESCRIPTION}

A middle-aged patient was referred for endoscopic removal of flat polyps in the ascending and descending colon. The intervention was unremarkable and during afternoon rounds the patient felt well with no abdominal pain. She did however complain of pain in the neck which she reported to have occasionally. On physical examination of the neck, a subcutaneous crepitus was noted on the right side and a CT scan was performed which revealed predominantly right-sided mediastinal and cutaneous emphysema as well as right-sided retroperitoneal but no intraperitoneal air (figures 1 and 2). Perforations after colonoscopy are rare; the most common presentation is abdominal pain and pneumoperitoneum. ${ }^{1}$ However, since parts of the ascending and descending colon are secondarily retroperitoneal, perforations may also result in pneumoretroperitoeneum, pneumomediastinum, cutaneous emphysema and even tension pneumothorax. ${ }^{2}$ Our patient's chief complaint was moderate pain in the neck which can be the presentation of retroperitoneal perforation. ${ }^{3}$ The case was managed

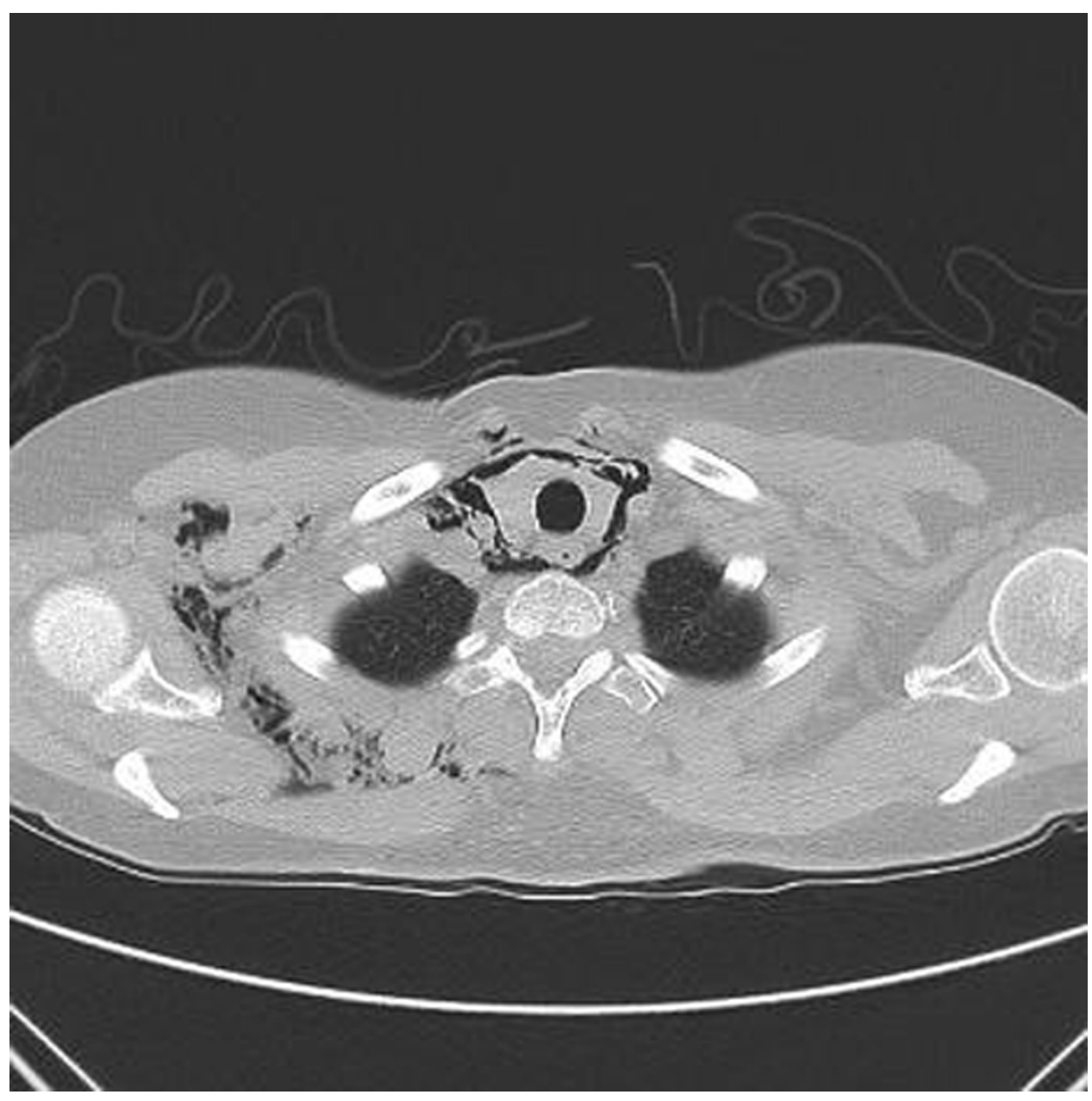

Figure 1 CT scan showing predominantly right-sided mediastinal and cutaneous emphysema. 


\section{BMJ Case Reports}

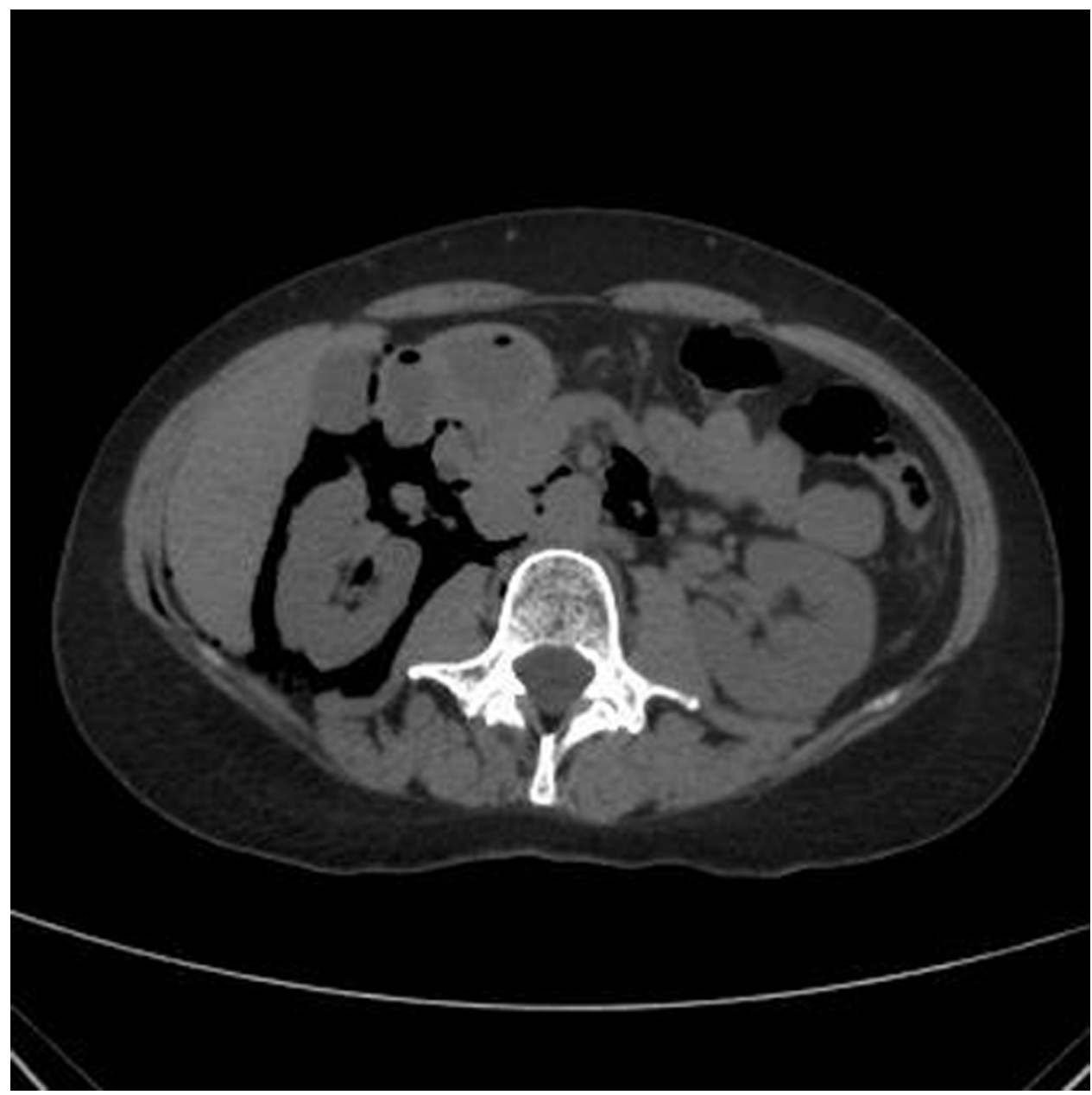

Figure 2 CT scan showing right-sided retroperitoneal but no intraperitoneal air.

with parenteral antibiotics and nil per os for 2 days and the patient could be discharged after 3 days of observation with clinical resolution of both cutaneous emphysema and pain in the neck.

\section{Competing interests None.}

Patient consent Not obtained.

\section{REFERENCES}

1. Araujo SE, Seid VE, Caravatto PP, et al. Incidence and management of colonoscopic colon perforations: 10 years' experience. Hepatogastroenterology 2009;56:1633-6.

2. Tam WC, Pollard I, Johnson RD. Case report: pneumomediastinum and pneumothorax complicating colonoscopy. J Gastroenterol Hepatol 1996;11:789-92.

3. Manjunath S, Trash DB. An unusual cause of 'pain in the neck'. Postgrad Med J 1997:73:745-6.

This pdf has been created automatically from the final edited text and images.

Copyright 2011 BMJ Publishing Group. All rights reserved. For permission to reuse any of this content visit http://group.bmi.com/group/rights-licensing/permissions.

BMJ Case Report Fellows may re-use this article for personal use and teaching without any further permission.

Please cite this article as follows (you will need to access the article online to obtain the date of publication).

Dumoulin FL, Textor J. An unusual presentation of a typical complication after endoscopic polypectomy. BMJ Case Reports 2011

10.1136/bcr.08.2011.4591, date of publication

Become a Fellow of BMJ Case Reports today and you can:

- Submit as many cases as you like

- Enjoy fast sympathetic peer review and rapid publication of accepted articles

- Access all the published articles

- Re-use any of the published material for personal use and teaching without further permission

For information on Institutional Fellowships contact consortiasales@bmjgroup.com

Visit casereports.bmj.com for more articles like this and to become a Fellow 